\title{
FERTILITY OF FROZEN RABBIT SEMEN
}

\author{
G. F. STRANZINGER, R. R. MAURER AND S. K. PAUFLER \\ Veterinary Institute, University of Göttingen, \\ 34 Göttingen, West Germany
}

(Received 17th Fuly 1970)

\begin{abstract}
Summary. Rabbit semen was extended in a tris-yolk-12.5\% DMSO extender and frozen in liquid nitrogen vapour or on a 'dry ice' block after glycerol had been added. No differences $(P>0 \cdot 10)$ were found between inseminations with liquid semen and semen frozen in pellets with regard to the number of young born or the pregnancy rate. Other methods produced significantly $(P<0.05)$ fewer young. Significantly $(P<0.05)$ more young were born to does inseminated $5 \mathrm{hr}$ after they received the ovulating hormone.
\end{abstract}

Rabbit semen has been frozen with differing results (Smith \& Polge, 1950; Fox, 1961; Fox \& Burdick, 1963; Sawada \& Chang, 1964; Wales \& O'Shea, 1968; O'Shea \& Wales, 1969). The fertility of frozen rabbit semen in the earlier reports was low. Since the ovulation time in the rabbit is known, it is a good laboratory animal in which to study the handling of spermatozoa in vitro.

Two ejaculates were collected within 20 min once weekly from fourteeen White Vienna male rabbits, using an artificial vagina. Semen volume and motility per ejaculate were recorded and those having $50 \%$ or more progressive motility were pooled. The pooled semen was diluted $1: 4$ with a tris-yolk dimethyl sulphoxide (DMSO) extender. The diluter was a slight modification of the tris-yolk extender reported by Steinbach \& Foote (1967), having the following composition: $3.028 \mathrm{~g}$ tris-hydroxymethylaminomethane $\left(\mathrm{C}_{4} \mathrm{H}_{11} \mathrm{NO}_{3}\right)$, $1.675 \mathrm{~g}$ citric acid $\left(\mathrm{C}_{6} \mathrm{H}_{8} \mathrm{O}_{7} \cdot \mathrm{H}_{2} \mathrm{O}\right), \mathrm{l} .250 \mathrm{~g}$ D-glucose $\left(\mathrm{G}_{6} \mathrm{H}_{12} \mathrm{O}_{6}\right), 15 \mathrm{ml}$ DMSO and twice distilled water to make a total volume of $100 \mathrm{ml}$. To the 100 $\mathrm{ml}$ were added $20 \mathrm{ml}$ egg yolk and 120,000 units each of penicillin and streptomycin. The $\mathrm{pH}$ was adjusted to 6.7 using citric acid. The sperm concentration of the extended semen was determined with a haemocytometer. The extended semen was divided into two parts and handled as follows: one part was placed in a $5^{\circ} \mathrm{C}$ cool room for 6 to $8 \mathrm{hr}$ until it was inseminated (liquid semen); the other part was cooled in a $5^{\circ} \mathrm{C}$ cool room for 1 to $3 \mathrm{hr}$ and glycerol $(6 \%$ of the extender volume) was added $30 \mathrm{~min}$ before freezing. The extended semen containing glycerol was placed in three different forms of container: $2 \cdot 5-\mathrm{ml}$ plastic ampoules, $0.3 \times 0.4 \times 20 \mathrm{~cm}$ coiled polyvinylchloride tubing and $0.5-\mathrm{ml}$ plastic straws, and frozen in liquid nitrogen vapour for 6 to $10 \mathrm{~min}$ or frozen as $0 \cdot 15-\mathrm{ml}$ pellets in holes on a 'dry ice' block for $10 \mathrm{~min}$ (frozen semen). The frozen semen was stored in liquid nitrogen until used for the inseminations.

The semen in the ampoules, tubing and straws was thawed in a $40^{\circ} \mathrm{C}$ water 
bath for 40 to $60 \mathrm{sec}$. The pellets were placed in a plastic bag and similarly thawed. Motilities were recorded after thawing and the semen divided into $0 \cdot 5-$ or $0.6-\mathrm{ml}$ insemination portions.

Each White Vienna doe inseminated was injected intravenously with $0.5 \mathrm{mg}$ luteinizing hormone (PLH, Armour) $/ \mathrm{kg}$ body weight to induce ovulation. Two trials were conducted, involving 339 inseminations. In the first trial, 223 does were artificially inseminated with $0.3 \mathrm{ml}$ liquid or $0.5 \mathrm{ml}$ frozen semen containing a minimum of $15 \times 10^{6}$ motile spermatozoa immediately following the $\mathbf{L H}$ injection. The kindling results were analysed using the analysis of variance and the Chi square test.

The results of insemination with liquid semen compared to semen frozen in ampoules and tubing are given in Table 1 . Significantly $(P<0.005)$ more young were produced from liquid semen. The percentage of does kindling was also higher $\left(P<0.005, \chi^{2}=42.4,1\right.$ d.f. $)$. No difference $(P>0 \cdot 10)$ was found between semen frozen in ampoules versus tubing.

TABLE 1

COMPARISON OF VARIOUS FREEZING METHODS

\begin{tabular}{l|c|c|c|c|c}
\hline $\begin{array}{c}\text { Semen } \\
\text { treatment }\end{array}$ & $\begin{array}{c}\text { Freezing } \\
\text { method }\end{array}$ & $\begin{array}{c}\text { No. of does kindling/ } \\
\text { total insem. (\%) }\end{array}$ & $\begin{array}{c}\text { Total } \\
\text { no. of } \\
\text { young }\end{array}$ & $\begin{array}{c}\text { No. of young/ } \\
\text { doe insem. }\end{array}$ & $\begin{array}{c}\text { No. of young/ } \\
\text { doe kindling }\end{array}$ \\
\hline Liquid & & $35 / 52(67 \cdot 3)$ & 226 & $4 \cdot 3$ & $6 \cdot 5$ \\
\hline Frozen & $\begin{array}{c}\text { Ampoule } \\
\text { Tubing }\end{array}$ & $\begin{array}{c}11 / 37(29 \cdot 8) \\
24 / 134(17 \cdot 9)\end{array}$ & $\begin{array}{c}38 \\
82\end{array}$ & $\begin{array}{c}1 \cdot 0 \\
0 \cdot 6\end{array}$ & $\begin{array}{c}3.5 \\
3 \cdot 4\end{array}$ \\
\hline
\end{tabular}

In the second trial, 116 does were artificially inseminated with $0.3 \mathrm{ml}$ liquid semen or $0.6 \mathrm{ml}$ frozen semen containing a minimum of $12 \times 10^{6}$ motile spermatozoa. After thawing, the frozen semen samples had motilities ranging from 25 to $50 \%$. LH was injected in fifty-seven does $5 \mathrm{hr}$ before the insemination while the remaining fifty-nine does were injected just before insemination.

The number of young resulting from the insemination of semen frozen in tubings, straws or as pellets was compared with the number resulting from the insemination of liquid semen. The results and significances are given in Table 2. No significant difference $(P>0 \cdot 10)$ was found between liquid and frozen pelleted semen with regard to the number of young born or the number of does kindling.

Does inseminated $5 \mathrm{hr}$ after the LH injection produced significantly more $(P<0.05)$ young than the comparable animals inseminated immediately following the ovulating injection.

The method of freezing semen was shown to have an influence on the fertilizing ability of the spermatozoa. Freezing rabbit semen as pellets was easily accomplished and gave the only comparable results to liquid semen in the number of young born. The maternal environment appeared to have an influence on the number of young born as more young were produced when the 
TABLE 2

COMPARISON OF VARIOUS FREEZING METHODS AND INSEMINATION TIMES

\begin{tabular}{|c|c|c|c|c|c|c|}
\hline $\begin{array}{c}\text { Semen } \\
\text { treatment }\end{array}$ & $\begin{array}{l}\text { Freezing } \\
\text { method }\end{array}$ & $\begin{array}{l}\text { Time between } \\
P L H \text { inject. } \\
\text { and insem } \\
\quad(h r)\end{array}$ & $\begin{array}{c}\text { No. of does kindling/ } \\
\text { total insem. }(\%)\end{array}$ & $\begin{array}{l}\text { Total } \\
\text { no. of } \\
\text { young }\end{array}$ & $\begin{array}{l}\text { No. of youngl } \\
\text { doe insem. }\end{array}$ & $\begin{array}{l}\text { No. of young/ } \\
\text { doe kindling }\end{array}$ \\
\hline \multirow[t]{2}{*}{ Liquid } & & $\begin{array}{l}5 \\
0\end{array}$ & $\begin{array}{l}13 / 20(65 \cdot 0) \\
10 / 20(50 \cdot 0)\end{array}$ & $\begin{array}{l}96 \\
56\end{array}$ & $\begin{array}{l}4 \cdot 8 \\
2 \cdot 8\end{array}$ & $\begin{array}{l}7 \cdot 4 \\
5 \cdot 6\end{array}$ \\
\hline & & Total & $23 / 40(57 \cdot 5)$ & 152 & $3 \cdot 8^{a}$ & $6 \cdot 6$ \\
\hline \multirow[t]{6}{*}{ Frozen } & Pellets & $\begin{array}{l}5 \\
0\end{array}$ & $\begin{array}{r}10 / 19(52 \cdot 6) \\
7 / 17(41 \cdot 2)\end{array}$ & $\begin{array}{l}71 \\
45\end{array}$ & $\begin{array}{l}3 \cdot 7 \\
2 \cdot 6\end{array}$ & $\begin{array}{l}7 \cdot 1 \\
6 \cdot 4\end{array}$ \\
\hline & & Total & $17 / 36(47 \cdot 2)$ & 116 & $3 \cdot 2^{a, b}$ & $6 \cdot 8$ \\
\hline & Tubing & $\begin{array}{l}5 \\
0\end{array}$ & $\begin{array}{l}5 / 12(41 \cdot 7) \\
3 / 12(25 \cdot 0)\end{array}$ & $\begin{array}{l}25 \\
11\end{array}$ & $\begin{array}{l}2 \cdot 1 \\
0.9\end{array}$ & $\begin{array}{l}5 \cdot 0 \\
3 \cdot 7\end{array}$ \\
\hline & & Total & $8 / 24(33 \cdot 3)$ & 36 & $1 \cdot 5^{b, c}$ & $4 \cdot 5$ \\
\hline & Straws & $\begin{array}{l}5 \\
0\end{array}$ & $\begin{array}{ll}2 / 8 & (25 \cdot 0) \\
1 / 8 & (12 \cdot 5)\end{array}$ & $\begin{array}{l}9 \\
6\end{array}$ & $\begin{array}{l}1.1 \\
0.8\end{array}$ & $\begin{array}{l}4 \cdot 5 \\
6 \cdot 0\end{array}$ \\
\hline & & Total & $3 / 16(18.8)$ & 15 & $0.9^{c}$ & 5.0 \\
\hline
\end{tabular}

a,b,c Means with the same superscript are not significantly different $(P<0.05)$.

spermatozoa were in the reproductive tract for approximately 5 to $7 \mathrm{hr}$ versus the normal 10 to $12 \mathrm{hr}$. This is in agreement with the work of Maurer, Whitener \& Foote (1969) which showed that the highest percentage of cleaved ova were found when does were inseminated $5 \mathrm{hr}$ after the ovulating injection.

This investigation was supported by a grant from Lower Saxony. Dr R. R. Maurer was supported by a Lalor Research Award and by the Alexander von Humboldt Stiftung.

\section{REFERENCES}

Fox, R. R. (1961) Preservation of rabbit spermatozoa: fertility results from frozen semen. Proc. Soc. exp. Biol. Med. 108, 663.

Fox, R. R. \& BuRdick, J. F. (1963) Preservation of rabbit spermatozoa: ethylene glycol us glycerol for frozen semen. Proc. Soc. exp. Biol. Med. 113, 853.

MaURer, R. R., Whitener, R. H. \& Foote, R. H. (1969) Relationship of in vivo gamete aging and exogenous hormones to early embryo development in rabbits. Proc. Soc. exp. Biol. Med. 131, 882.

O'SheA, T. \& Wales, R. G. (1969) Further studies of the deep freezing of rabbit spermatozoa in reconstituted skim milk powder. Aust. F. biol. Sci. 22, 709.

SAWAdA, Y. \& Grang, M. C. (1964) Motility and freezing capacity of rabbit spermatozoa after freezing in a medium containing dimethyl sulfoxide. Fert. Steril. 15, 222.

SMITH, A. U. \& PoLGE, C. (1950) Survival of spermatozoa at low temperatures. Nature, Lond. 166, 668.

SteinBach, J. \& Foote, R. H. (1967) Osmotic pressure and pH effects on survival of frozen bovine spermatozoa. F. Dairy Sci. 50, 205.

WALEs, R. G. \& O'ShEA, T. (1968) The deep freezing of rabbit spermatozoa. Aust. F. biol. Sci. 21, 831. 